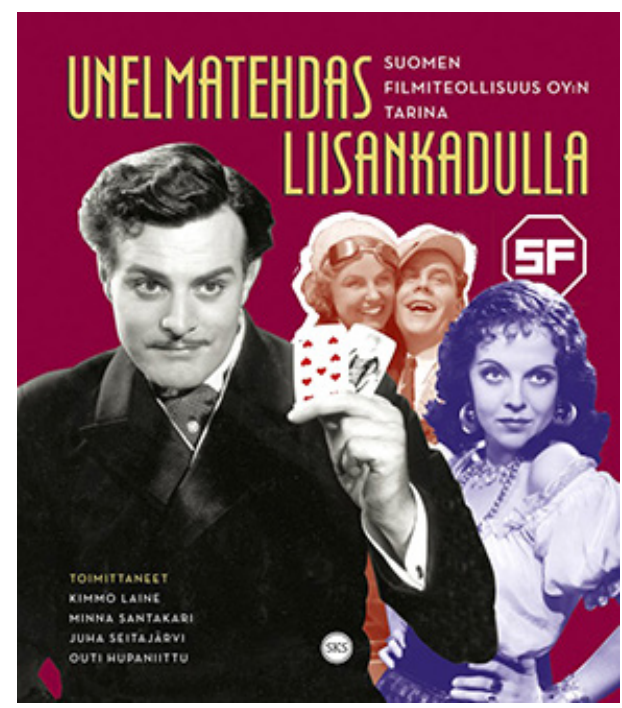

\section{UUSIA NÄKÖKULMIA SUOMEN FILMITEOLLISUUDEN HISTORIAAN}

Kimmo Laine, Minna Santakari, Juha Seitajärvi \& Outi Hupaniittu (toim.) (2019) Unelmatehdas Liisankadulla: Suomen Filmiteollisuus Oy:n tarina. Helsinki: Suomalaisen Kirjallisuuden Seura, 359 s.
Unelmatehdas Liisankadulla on vaikuttava suomalaisen elokuvahistorian ja -tutkimuksen merkkiteos, joka tuo uusia näkökulmia ja aineistomateriaalia suomalaisen elokuvakulttuurin tutkimukseen. Se rakentaa monipuolisen kulttuuripoliittisen kuvan suomalaisen elokuvatuotannon värikkäästä historiasta ja tuo esille merkittävää uutta tietoa myös useiden jo läpikotaisin tutkittujen elokuvien tuotannosta, levityksestä, vastaanotosta ja poliittisesta roolista.

Suomen Filmiteollisuus Oy (SF) oli suomalaisen elokuvatuotannon "kultakauden" suurin elokuvastudio. Toimitusjohtaja Toivo "Maisteri" Särkän johdolla tuotettiin kaikkiaan 237 pitkää elokuvaa neljän vuosikymmenen aikana. Merkittävät ohjaajat kuten Edvin Laine ja Matti Kassila sekä monet valovoimaiset kotimaisen elokuvan tähdet, keskeisimpinä Tauno Palo ja Ansa Ikonen, toimivat Suomen "unelmatehtaalla". Siellä valmistuivat myös suomalaisen elokuvahistorian keskeiset klassikot Tuntematon sotilas (1955) ja Kaasua Komisario Palmu (1961). Studion mittava kulttuurihistoria suorastaan vaatii SF:n toimintavuosien laajamittaista ja monipuolista kuvausta ja tässä Unelmatehdas Liisankadulla -kirja onnistuu erinomaisesti.

Teos sisältää elokuva- ja mediahistoriallisten näkökulmien lisäksi myös elokuvien tuotantopoliittista analyysiä, tutkimusta elokuvien esteettisistä ja taidehistoriallisista piirteistä sekä materiaalia elokuvien markkinoinnista. Teoksen toimittajakunta koostuu arvostetuista elokuvahistorijoitsijoista (Kimmo Laine, Outi
Hupaniittu, Juha Seitajärvi) ja elokuva-alan toimijoista (Minna Santakari), joiden asiantuntemus ja kokemus näkyvät myös taitavassa tekstinkäsitelyssä: kirja yhdistää onnistuneesti yhteiskuntafilosofista pohdintaa kirjoitustyyliin, joka sopii mainiosti myös laajemmalle yleisölle.

\section{Suomalaisen elokuvan tuotantotutkimusta}

Teoksen yksittäisissä luvuissa kirjoittajat käyttävät onnistuneesti hyväkseen eri tutkimusalojen metodologisia näkökulmia samalla soveltaen niihin monimuotoisia tutkimushistoriallisia tarkastelumalleja. Teoksen artikkeleissa käytetty materiaali on myös laajaa ja mukaan on otettu muun muassa markkinointiaineistoa, tilikirjoja, tuotantokustannuksia, katsojalukuja, aikalaiskritiikkiä, haastatteluita ja elokuvien estetiikkaa ja narratologisia kuvioita tutkivaa lähilukua. Lähteitä on käytetty tarkasti ja tiiviisti, ja kirjassa esitetään myös yksityiskohtaisia tarinoita elokuvatuotannon kimuranteista kuvioista. Esimerkiksi Outi Hupaniitun tutkimusmateriaali pohjautuu tuotantoyhtiön taloudelliseen kirjanpitoon ja luo yksityiskohtaisen kuvan elokuva-alan tuotanto- ja talouspolitiikasta, kun taas Minna Santakarin artikkeli piirtää tarkan kuvan lavastajien työnteosta Liisankadun studioilla.

Luvut, joissa tutkimuskohteena on jokapäiväinen työnteko, kertovat siitä, kuinka elokuvatuotanto käytännössä studioilla tapahtui ja miten sitä koordinoitiin hallintotasolla. Nämä 
kuvaukset tuottavat merkittävää tuotantopoliittista tutkimusmateriaalia elokuvatuotannon taloudellisista ja hallinnollisista kuvioista.

Teos voitaisiinkin luokitella osaksi kansainvälisessä elokuvatieteessä suurta huomiota herättänyttä "tuotantotutkimusta", joka paneutuu perinteisen elokuvien tekstuaalisen analyysin sijaan tuotantokulttuurien ja -prosessien analyysiin. Kyseinen tutkimussuuntaus (kärkiniminä yhdysvaltalaiset John Caldwell ja Vicki Mayer) keskittyy tarkastelemaan kaksijakoista elokuvien tuotantokoneistoa. Tässä jaottelussa above-the-line (eli luovat toimijat, kuten tuottajat ja ohjaajat) ja below-the-line (eli käytännön toimijat, kuten lavastajat tai muonitustoiminta) tekijät erittelevät elokuvatuotannon prosessin näkyvämpään ja suurta yleisöä kiinnostavaan "luovaan kaartiin" ja tuotannolle elinehtoiseen, mutta usein näkymättömään kulisseissa tapahtuvaan toimintaan. Tämän kirjan ansioksi onkin luettava se, etteivät sen artikkelit käsittele pelkästään niin sanotusti "suurten tekijöiden" kuvaa vaan esittelevät myös laajemmin työtä kulisseissa, alueella jossa tuotantopolitiikka on hyvinkin erilaista kuin hallintokonttoreissa tai aikakauslehtien etusivuilla. Tällaista suomalaisen elokuvan tutkimuksellista analyysiä on jo kaivattu.

Teos on vahvimmillaan yhdistäessään näkökulmia tuotantoprosesseista, elokuvapolitiikasta, yhteiskunnallisista tekijöistä ja elokuvien kulutuksesta. Esimerkiksi Markku Koski käsittelee ansiokkaasti kulttuuritehtaan ja -teollisuuden käsitettä Särkän henkilökuvan kautta. Tätä tutkimussuuntauksellista linjausta jatkaa myös Tommi Römpötti analysoidessaan nuorisoelokuvien roolia SF:n pyrkimyksissä käsitellä yhteiskunnallisia kysymyksiä sekä houkutella kadonnutta nuorta yleisöä takaisin elokuvateattereihin. Näin piirtyy myös kokonaiskuva SF:n taloudellisista, esteettisistä, ideologisista ja käytännöllisistä toimintaperiaatteista.

Vaikka teos ei pyrikään omaksumaan erityisen teoreettista lähestymistapaa, sen korkeatasoinen ja monipuolinen panos esimerkiksi kansallisen elokuvan käsitteen ymmärtämiseksi valottaa elokuvatuotannon keskeistä roolia kansallisen muistin kehityksessä ja laajemmassa yhteiskuntapolitiikassa. Toisaalta, vaikka kirja sisältää laajalti materiaalia tuotantokuvioista ja elokuvien laajemmasta kulttuurimerkityksestä, se ei myöskään karttele vaikeita kysymyksiä ja kriittisiä näkökulmia yhteiskunnallisista kipupisteistä. Esimerkiksi Riikka Pennasen katsauksessa Assi Nortian tähteydestä rakentuu mielenkiintoinen näkökulma aikalaiseen vähemmistöpolitiikkaan Nortian "rodullistetun" tähtipersoonan myötä. Myös Raija Talvion artikkelissa Lasse Pöystin tähdittämästä Suomisen Olli -elokuvasarjasta muotoutuu kriittinen näkökulma jatkosodasta kotiutuvien miesten kotiuttamisongelmiin ja täten myös laajempiin yhteiskunnallisiin ja ulkopoliittisiin realiteetteihin.

Muutamia kirjan lukuja vaivaa hieman tietokirjamainen esitystapa. Näiden lukujen sisältö koostuu valtavasta määrästä faktoja ja huomioita elokuvien kuvauksista tai kuvauspaikoista tapahtumien merkittävyyden analyysin jäädessä vähemmälle huomiolle. Esimerkiksi kartanoiden tai puvustuksen osuudesta elokuvien laajempien yhteiskunnallisten virtausten ja viitekehyksien tulkkina voisi saada nykyistä enemmänkin irti. Myös elokuvien työpolitiikassa olisi nykyistä enemmän mahdollisuuksia sosiologiselle luokka-analyysille. Vaikka elokuvien puvustajista ja säveltäjistä löytyy jo nyt runsaasti taustatietoa, laajempaa kuvaa studioiden tuotantokoneiston eri tasoista ja rooleista kaivataan edelleen.

Esimerkiksi Anu Juvan artikkeli avaa sujuvasti korkea- ja matalakulttuurin eroja SF:n elokuvien musiikissa valottaen samalla elokuvien iskelmähittien merkitystä. Juva kertoo myös, miten Reino Helismaan "rillumareit" liittyivät konkreettisesti SF:n brändäykseen. Laulut toimivat osana yhtiön monimediaalista tuotantolinjaa, johon yhtiön hallinto panosti, koska näin saatiin rakennettua tarttumapintaa yleisöön. Oli nimittäin havaittu, että yleisö tuli teattereihin pääasiassa kuuntelemaan elokuvien iskelmämusiikkia. Artikkelissa on myös mielenkiintoisia huomiota Einar Englundin ja Helismaan sävellystyöskentelystä SF:llä. Elokuvien iskelmien tai modernin orkesterimusiikin havaittiin luovan monenlaisia populaari- ja taide-elokuvan viitteitä, jotka eivät kuitenkaan olleet toisiaan poissulkevia. Tämä on tunnistettavissa esimerkiksi Komisario Palmu -elokuvasarjaan sävelletyssä monipuolisessa musiikissa. 


\section{SF:n kansainvälisyydestä}

Teos sisältää siis laajalti materiaalia SF:n yhteiskunnallisesta ja kulttuuripoliittisesta panoksesta, mutta samalla kirja laajentaa ymmärrystä "elokuvista elokuvina". Kimmo Laine kirjoittaa luvussaan SF:n genrekuvioista: "käsillä olevassa teoksessakin nousee esiin vaihteleva kirjo iskelmäelokuvista ja kansainvälisistä seikkailukomedioista pohjalaisdraamoihin ja kartanoromantiikkaan" (s. 190). Genretuotanto ja elokuvalliset syklit liittyvät usein elokuvateollisuuden kansainväliseen kulttuuri- ja markkinavaihtoon. Kyseiset tuotantokuviot ilmenevät käytännössä elokuvien sisällössä, jossa esimerkiksi juonikuvioiden tai esteettisten valintojen pohjalta voidaan rakentaa laajempaa ymmärrystä suomalaisen elokuvan kansainvälisyydestä.

Tämä tulee esille kirjan useissa luvuissa, jotka keskittyvät elokuvan kansainvälisten vaikutusten, yhteistuotannon, levityksen tai vastaanoton käsittelyyn. Esimerkiksi Anneli Lehtisalon, Tytti Soilan, Aymeric Pantetin ja Jaakko Seppälän katsaukset esittävät tärkeitä huomiota genretuotannon transnationaalista luonteesta. Ne vahvistavat käsitystä siitä, ettei suomalainen elokuvakulttuuri muotoutunut eristyksissä vaan vuorovaikutuksessa kansainvälisten tekijöiden kanssa. Teos avaa tätä monimuotoista tuotantohistoriaa ja -politiikkaa uudesta näkökulmasta ja edistää korkeatasoista tutkimusta myös usein läpipohdittujen elokuvien merkityksestä. Näin tapahtuu esimerkiksi Pantetin lyhyessä katsauksessa Tuntemattoman sotilaan (1955) epäonnekkaasta Cannesin valloituksesta, joka valottaa romahtaneiden levitysneuvottelujen taustaa uuden arkistomateriaalin välityksellä.

Artikkelit kansainvälisistä yhteistuotantokuvioista ovat kiinnostavia ja tuovat uutta tietoa muun muassa Mika Waltarin käsikirjoitukseen perustuvasta Verta käsissämme -elokuvasta (1958), josta tuotettiin yhteistyössä Svea Filmin kanssa suomen- ja ruotsinkieliset versiot (Ingen morgondag 1957). Myös Seppälän tutkimuksessa Eddie Constantine -elokuvien juonikaavojen ja markkinoinnin muokkaamisessa suomalaisiksi populaarielokuviksi Ei ruumita makuuhuoneseen (1959) ja Kovaa peliä Pohjolassa (1959) näkyy kansainvälisen elokuvakulttuurin vaikutus sekä elokuvien sisältöön että niiden saamaan kritiikkiin. Kyseisten elokuvien vaatimaton menestys kertoo toisaalta myös paljon vallalla olleesta makukulttuurista, jonka takia kotimaisten elokuvien genremuunnelmat eivät olleet tarpeeksi kiinnostavia kotimaiselle yleisölle.

Kirjassa esitetyt huomiot muun muassa elokuvallisten lajityyppien osuudesta kansallisen elokuvakulttuurin jatkuvuuden luomisessa sekä keinoista, joilla tätä jatkuvuutta voitaisiin hyödyntää markkinointikeinoina kotimaisen yleisön huomion herättämiseksi, ovat merkittäviä elokuvatutkimusta laajentavia havaintoja. Koska kyseessä on elokuvatutkimuksellisesti korkealuokkainen aineisto, se luultavasti kiinnostaisi myös kansainvälisiä alan tutkijoita. Olisi luontevaa harkita käännösversiota teoksesta, sillä kyseessä on merkittävä panos elokuvien kansainväliseen kulttuurihistorialliseen tutkimukseen. Lisäksi teoksen yksityiskohtainen ja monialainen lähestymistapa tuo uusia näkökulmia elokuvien studiohistorialliseen tutkimukseen ja kansainvälisen kulttuurivaihdon merkitykseen niin sanottujen "pienten maiden" elokuvakulttuureissa. Näissä kun elokuvien tuotantopolitiikka ja liiketaloudelliset kysymykset saavat usein huomattavan erilaisia painotuksia kuin esimerkiksi Hollywoodissa.

\section{Pietari Kääpä}

FT, media ja viestintä, Warwickin yliopisto 